\title{
Cloning, expression and characterisation of an HtrA-like serine protease produced in vivo by Mycobacterium leprae
}

\author{
Michelle Lopes Ribeiro-Guimarães ${ }^{1,2}$, Eliana Blini Marengo ${ }^{3}$, Antonio Jorge Tempone ${ }^{1}$, \\ Julio Jablonski Amaral' ${ }^{1,2}$, Clécio F Klitzke ${ }^{3}$, Erika K Xavier da Silveira', \\ Fernanda Calheta Vieira Portaro ${ }^{3}$, Maria Cristina Vidal Pessolani ${ }^{1 /+}$
}

\begin{abstract}
${ }^{1}$ Laboratório de Microbiologia Celular, Instituto Oswaldo Cruz-Fiocruz, Av. Brasil 4365, 21040-900 Rio de Janeiro, RJ, Brasil ${ }^{2}$ Instituto de Bioquímica Médica, Universidade Federal do Rio de Janeiro, Rio de Janeiro, RJ, Brasil ${ }^{2}$ Laboratório de Imunoquímica e LETA, Centro de Toxinologia Aplicada, Instituto Butantan, São Paulo, SP, Brasil
\end{abstract}

Members of the high temperature requirement A (HtrA) family of chaperone proteases have been shown to play a role in bacterial pathogenesis. In a recent report, we demonstrated that the gene ML0176, which codes for a predicted HtrA-like protease, a gene conserved in other species of mycobacteria, is transcribed by Mycobacterium leprae in human leprosy lesions. In the present study, the recombinant ML0176 protein was produced and its enzymatic properties investigated. M. leprae recombinant ML0176 was able to hydrolyse a variety of synthetic and natural peptides. Similar to other HtrA proteins, this enzyme displayed maximum proteolytic activity at temperatures above $40^{\circ} \mathrm{C}$ and was completely inactivated by aprotinin, a protease inhibitor with high selectivity for serine proteases. Finally, analysis of M. leprae ML0176 specificity suggested a broader cleavage preference than that of previously described HtrAs homologues. In summary, we have identified an HtrA-like protease in M. leprae that may constitute a potential new target for the development of novel prophylactic and/or therapeutic strategies against mycobacterial infections.

Key words: Mycobacterium leprae - HtrA2 - protease - enzymatic activity - FRET peptides - pathogenesis

Infections caused by species of the genus Mycobacterium continue to adversely affect the lives of millions worldwide. Leprosy, caused by Mycobacterium leprae, remains a public health problem in several developing countries, including Brazil, and is responsible for the legacy of countless numbers of people with permanent physical deformities (WHO 2009b). In addition, tuberculosis, caused by Mycobacterium tuberculosis, is responsible for 2-3 million annual deaths (WHO 2009a). Furthermore, infections in immunocompromised individuals caused by opportunistic mycobacterial species, such as Мycobacterium avium and Mycobacterium intracellulare, belonging to the $M$. avium complex, have gained additional epidemiological importance since the emergence of AIDS (Garcia Garcia et al. 2005). Deciphering the mechanisms implicated in mycobacterial pathogenesis is currently a major challenge in leprosy and tuberculosis research and may eventually lead to the development of new prophylactic and/or therapeutic strategies.

Members of the high temperature requirement $\mathrm{A}$ (HtrA) family are envelope-associated serine proteases that perform crucial functions, involving protein quality control in the periplasmic space, acting as both molecular chaperones and proteases (Pallen \& Wren 1997, Page \& Di Cera 2008). It has been shown in a wide range of bacte-

Financial support: FAPERJ; CNPq, CAPES (to MLRG and JJA)

+ Corresponding author: cpessola@ioc.fiocruz.br

Received 11 July 2009

Accepted 30 November 2009 rial species that HtrA proteases are essential for virulence and survival under environmental stress. In fact, mutations in the htrA gene have been shown to affect bacterial tolerance to both thermal and environmental stress and to produce a loss of virulence, as shown in Porphyromonas gingivalis, Chlamydia trachomatis, Salmonella typhimurium, Streptococcus pyogenes, Listeria monocytogenes and Burkhoderia cenocepacia (Jones et al. 2001, Biwas \& Biwas 2005, Stack et al. 2005, Mo et al. 2006, Flannagan et al. 2007, Huston et al. 2008, Yuan et al. 2008, Lewis et al. 2009). Biochemical analysis of the three HtrA proteins found in Escherichia coli, DegP, DegQ and DegS, has provided insights into their function and regulation (Lipinska et al. 1989, 1990, Kolmar et al. 1996, Krojer et al. 2008). However, the function of this protein family in Gram positive bacteria remains unclear.

A recent comparison of the protease-coding genes present in the genomes of $M$. leprae, $M$. tuberculosis, Mycobacterium bovis and Mycobacterium paratuberculosis revealed that three well-conserved putative HtrA-like genes are shared by all four species (RibeiroGuimarães \& Pessolani 2007). The htrA2 gene in mycobacterium is part of an operon in which the genes coding for the two-component regulatory system MprA-MprB are located upstream of htrA2 (Zahrt et al. 2003). Recent studies have shown that $M$. tuberculosis HtrA2 is positively regulated by MprAB (He \& Zahrt 2005), which also regulates other stress-response genes (He et al. 2006). Moreover, it was shown that MprAB is required by $M$. tuberculosis for growth in vivo (Zahrt \& Deretic 2001), suggesting that HtrA members are essential for mycobacterial persistence in the host. This idea is reinforced by recent findings indicating transcription of 
putative htrA2 (ML0176) and htrA4 (ML2659) genes by $M$. leprae isolated from skin biopsies of multibacillary leprosy patients (Ribeiro-Guimarães et al. 2007), as well as expression of the HtrA4 protein by armadillo-derived M. leprae (Marques et al. 2008).

Deciphering the biology of M. leprae has constituted one of the greatest challenges for microbiologist over time due to its inability to grow in vitro and the absence of experimental models that mimic the disease observed in humans. However, the $M$. leprae genome sequence has recently become available, providing an opportunity to study the enzymes of this microorganism, which are inaccessible for direct study. For the first time, the present study demonstrates that the recombinant $M$. leprae HtrA2 exhibits proteolytic activity toward synthetic and naturally-occurring peptides, revealing physicochemical properties of a typical HtrA-like protease.

\section{MATERIALS AND METHODS}

Materials - The fluorescence resonance energy transfer (FRET) peptides used in the present paper (Table I) were synthesised and purified, as described elsewhere (Hirata et al. 1995). The purity and the molecular masses of these peptides were determined by high performance liquid chromatography (HPLC) and by matrix assisted laser desorption/ionisation time-of-flight mass spectrometry (MS) (TofSpec-E, Micromass, UK), respectively. No-RR-methylcoumarin (MCA), dynorphin A, neurotensin 1-13, bradykinin and angiotensin I peptides as well as the protease inhibitors phenylmethylsulfonyl fluoride (PMSF) and aprotinin were purchased from Sigma Co (St. Luis, MO). Trypsin was purchased from Roche Diagnostics (Indianapolis, IN).

Cloning, expression and purification of rHtrA2 - The primers for the $h t r A 2$ gene were constructed to correspond to the 5' and 3 ' ends of the open reading frame previously identified. The sequences of 5' and 3' primers were 5 -GTTGGAATTCATGATTCCGCCCGGT-3` and 5'ACAACTCGAGCTCTCGATTAT TAAT-3', respectively. The underlined sequences represent the sites for the restriction enzymes EcoRI and XhoI, respectively, incorporated into the primers for subsequent cloning. The gene was PCR amplified from M. leprae genomic DNA with Deep Vent DNA polymerase. PCR was carried out using a PTC- $100^{\mathrm{TM}}$ (MJ Research, Inc) at an annealing temperature of $58^{\circ} \mathrm{C}$. The PCR product was gel purified and digested with EcoRI and XhoI followed by cloning into pET32a-c (+) vector (Novagen, San Diego, $\mathrm{CA})$ previously digested with the same enzymes. Overexpression and purification of the M. leprae HtrA2 protein were performed according to the QIAexpressionist manual (QIAGEN, Valencia, CA). Briefly, E. coli BL21$\mathrm{AI}^{\mathrm{TM}}$ harbouring the recombinant plasmid was grown up to an $\mathrm{OD}_{600}$ of 0.8 in ampicillin-containing Luria-Bertani (LB) medium. Expression of rHtrA2 was then induced by addition of $1 \mathrm{mM}$ isopropyl beta-D-thiogalactoside (IPTG) and cultures were incubated at $37^{\circ} \mathrm{C}$ for another $3 \mathrm{~h}$. Cells were harvested, ressuspended in lysis buffer (100 $\mathrm{mM} \mathrm{NaH}_{2} \mathrm{PO}_{4}, 10 \mathrm{mM}$ Tris $\mathrm{Cl} \mathrm{pH} \mathrm{8.0)} \mathrm{and} \mathrm{disrupted}$ by sonication. Debris was removed by centrifugation at

TABLE I

Kinetic parameters for the degradation of substrates derived from Abz-GFSPFRQ-EDDnp by rHtrA2

\begin{tabular}{|c|c|c|c|c|c|c|c|c|c|c|c|}
\hline \multicolumn{9}{|c|}{ Substrates (Abz-...-EDDnp) } & \multirow{2}{*}{$\begin{array}{c}\mathrm{K}_{\mathrm{m}}{ }^{b} \\
(\mu \mathrm{M})\end{array}$} & \multirow{2}{*}{$\begin{array}{l}\mathrm{k}_{\mathrm{cat}} \\
\left(\mathrm{s}^{-1}\right)\end{array}$} & \multirow{2}{*}{$\begin{array}{c}\mathrm{k}_{\mathrm{cat}} / \mathrm{K}_{\mathrm{m}} \\
(\mathrm{s} \cdot \mathrm{mM})^{-1}\end{array}$} \\
\hline $\mathrm{N}$ & $\mathrm{P}_{6}$ & $\mathrm{P}_{5}$ & $\mathrm{P}_{4}$ & $\mathrm{P}_{3}$ & $\mathrm{P}_{2}$ & $\mathrm{P}_{1}$ & $\downarrow^{a}$ & $\mathrm{P}_{1}^{\prime}$ & & & \\
\hline 1 & G & $\mathrm{F}$ & $\mathrm{S}$ & $\mathrm{P}$ & $\underline{\mathrm{R}}$ & $\mathrm{R}$ & $\downarrow$ & $\mathrm{Q}$ & $3.16 \pm 0.43$ & $63.00 \pm 3.0$ & 19.90 \\
\hline 2 & G & $\mathrm{F}$ & $\mathrm{S}$ & $\mathrm{P}$ & $\underline{D}$ & $\mathrm{R}$ & & $\mathrm{Q}$ & $\mathrm{nh}$ & $\mathrm{nh}$ & $\mathrm{nh}$ \\
\hline 3 & G & $\mathrm{F}$ & $\mathrm{S}$ & $\mathrm{P}$ & $\underline{F}$ & $\mathrm{R}$ & $\downarrow$ & $\mathrm{Q}$ & $6.96 \pm 0.64$ & $4.80 \pm 0.30$ & 0.68 \\
\hline 4 & G & $\mathrm{F}$ & $\mathrm{S}$ & $\mathrm{P}$ & $\underline{\mathrm{A}}$ & $\mathrm{R}$ & $\downarrow$ & $\mathrm{Q}$ & $3.40 \pm 0.36$ & $9.40 \pm 0.50$ & 2.76 \\
\hline 5 & G & $\mathrm{F}$ & $\mathrm{S}$ & $\mathrm{P}$ & $\underline{S}$ & $\mathrm{R}$ & $\downarrow$ & $\mathrm{Q}$ & $9.48 \pm 0.90$ & $27.00 \pm 3.00$ & 2.85 \\
\hline 6 & G & $\mathrm{F}$ & $\mathrm{S}$ & $\mathrm{P}$ & $\underline{P}$ & $\mathrm{R}$ & $\downarrow$ & $\mathrm{Q}$ & $4.58 \pm 0.90$ & $4.20 \pm 0.30$ & 0.92 \\
\hline 7 & G & $\mathrm{F}$ & $\mathrm{S}$ & $\underline{I}$ & $\mathrm{~F}$ & $\mathrm{R}$ & $\downarrow$ & $\mathrm{Q}$ & $2.09 \pm 0.20$ & $19.00 \pm 1.00$ & 9.13 \\
\hline 8 & G & $\mathrm{F}$ & $\mathrm{S}$ & $\underline{F}$ & $\mathrm{~F}$ & $\mathrm{R}$ & $\downarrow$ & $\mathrm{Q}$ & $7.78 \pm 0.78$ & $26.00 \pm 2.00$ & 3.34 \\
\hline 9 & G & $\mathrm{F}$ & $\mathrm{S}$ & $\underline{\mathrm{L}}$ & $\mathrm{F}$ & $\mathrm{R}$ & $\downarrow$ & $\mathrm{Q}$ & $2.04 \pm 0.19$ & $6.60 \pm 0.50$ & 3.23 \\
\hline 10 & G & $\mathrm{F}$ & $\underline{\mathrm{P}}$ & $\mathrm{P}$ & $\mathrm{F}$ & $\mathrm{R}$ & $\downarrow$ & $\mathrm{Q}$ & $5.30 \pm 0.41$ & $3.70 \pm 0.25$ & 0.70 \\
\hline 11 & G & $\mathrm{F}$ & $\underline{F}$ & $\mathrm{P}$ & $\mathrm{F}$ & $\mathrm{R}$ & $\downarrow$ & $\mathrm{Q}$ & $1.96 \pm 0.20$ & $10.00 \pm 1.00$ & 5.10 \\
\hline 12 & G & $\mathrm{F}$ & $\underline{\mathrm{R}}$ & $\mathrm{P}$ & $\mathrm{F}$ & $\mathrm{R}$ & $\downarrow$ & $\mathrm{Q}$ & $3.18 \pm 0.30$ & $31.00 \pm 3.00$ & 9.75 \\
\hline 13 & G & $\mathrm{F}$ & $\underline{S}$ & $\mathrm{P}$ & $\mathrm{F}$ & $\mathrm{R}$ & $\downarrow$ & $\mathrm{Q}$ & $6.96 \pm 0.64$ & $4.80 \pm 0.30$ & 0.69 \\
\hline 14 & G & $\mathrm{F}$ & $\underline{\mathrm{A}}$ & $\mathrm{P}$ & $\mathrm{F}$ & $\mathrm{R}$ & $\downarrow$ & $\mathrm{Q}$ & $6.27 \pm 0.60$ & $5.20 \pm 0.40$ & 0.83 \\
\hline 15 & G & $\mathrm{F}$ & $\underline{E}$ & $\mathrm{P}$ & $\mathrm{F}$ & $\mathrm{R}$ & $\downarrow$ & $\mathrm{Q}$ & $2.83 \pm 0.28$ & $2.00 \pm 0.15$ & 0.71 \\
\hline
\end{tabular}

$a$ : cleavage sites determined by mass spectrometry analysis are indicated by $\downarrow ; b$ : assays were carried out in a $50 \mathrm{mM}$ phosphate buffer, $\mathrm{pH} 8.0$, at $37^{\circ} \mathrm{C}$. The kinetic parameters were obtained in the presence of $1 / 10-10$ times the $\mathrm{K}_{\mathrm{m}}$ value of peptide substrate and 10-100 nM of rHtrA2, with a substrate consumption of less than 5\%. The velocity was recorded for 5-15 min and the parameters were calculated as mean value $( \pm \mathrm{SD})$. All enzymatic assays were performed in triplicate. nh: no hydrolysis detected. 
$10,000 \mathrm{~g}$ for $15 \mathrm{~min}$ at $4^{\circ} \mathrm{C}$ and rHtrA2 was purified from the supernatant by adding $1 \mathrm{~mL}$ of a $50 \%$ Ni-NTA slurry (QIAGEN) pre-equilibrated in lysis buffer to $4 \mathrm{~mL}$ of the lysate. After incubation for $1 \mathrm{~h}$ at $4^{\circ} \mathrm{C}$, the lysateNi-NTA mixture was loaded into a column. Unbound proteins were removed by washing the column with two column volumes of lysis buffer. The column was washed twice with $4 \mathrm{~mL}$ of $100 \mathrm{mM} \mathrm{NaH}_{2} \mathrm{PO}_{4}$ and $10 \mathrm{mM}$ Tris. $\mathrm{Cl}$, pH 6.3 and the recombinant protein was eluted with four column volumes of $100 \mathrm{mM} \mathrm{NaH}_{2} \mathrm{PO}_{4} \mathrm{pH}$ 4.5. Fractions were analysed by SDS-PAGE and Western Blot. Nitrocellulose membranes were probed with an anti-6xHis tag antibody (New England Biolabs, Ipswich, MA). The purified enzyme was stored in $50 \%$ glycerol at $-20^{\circ} \mathrm{C}$.

HPLC analysis of rHtrA2 - The fractions eluted from the Ni-NTA matrix enriched in rHtrA2 were concentrated at a flow rate of $1.0 \mathrm{~mL} / \mathrm{min}$ in a Superdex ${ }^{\mathrm{TM}}$ 75 gel filtration column (GE Healthcare Life Science do Brasil, São Paulo, Brazil) pre-equilibrated in $0.05 \mathrm{M}$ sodium phosphate and $0.15 \mathrm{M} \mathrm{NaCl}, \mathrm{pH}$ 6.8. Proteincontaining fractions were analysed by SDS-PAGE followed by silver staining. Protein concentration was determined according to Bradford (Bradford 1976) using bovine serum albumin as a standard.

MS analysis of recombinant HtrA2 - The purified recombinant HtrA2 protein was digested with trypsin. The resulting peptides were then applied to a $0.2 \mathrm{x} 50 \mathrm{~mm}$ $\mathrm{C}_{18}$ capillary reverse phase column (Michrom BioResources, Auburn, CA) and eluted with an increasing acetonitrile gradient using a MicroPro capillary HPLC system (Eldex Laboratories, Napa, CA). The reversephase eluent was introduced directly into a Finnigan LCQ electrospray MS (Thermoquest, San Jose, CA). The peptides were analysed by MS or MS/MS followed by a search in the M. leprae database with Xcalibur Bioworks 3.1 turbo SEQUEST software (ThermoFinnigan, San Jose, CA) under the conditions and parameters previously described (Biet et al. 2007).

Enzyme assays of recombinant HtrA2 - The hydrolyses of the fluorescent substrates (stock solution in 10\% DMSO) were conducted at $37^{\circ} \mathrm{C}$ in $50 \mathrm{mM}$ Tris- $\mathrm{HCl}$, $\mathrm{pH}$ 8.0, containing $20 \mathrm{mM} \mathrm{NaCl}$. Hydrolysis of $\mathrm{N} \alpha$-RRMCA and the FRET substrates were monitored by measuring fluorescence at $\lambda \mathrm{em}=460 \mathrm{~nm}$ and $\lambda \mathrm{ex}=380 \mathrm{~nm}$ and $\lambda \mathrm{em}=420 \mathrm{~nm}$ and $\lambda \mathrm{ex}=320 \mathrm{~nm}$, respectively, with a Hitachi F-2000 spectrofluorimeter, as previously described (Oliveira et al. 2001). The slope was converted into moles of hydrolysed substrate per minute, based on the fluorescence curves of standard peptide solutions before and after total enzymatic hydrolysis with trypsin. A 1-cm path length cuvette containing $1 \mathrm{~mL}$ of substrate solution was placed in a thermostatically controlled cell compartment prior to adding the enzyme solution. Enzyme concentrations ranged from 10-100 nM and FRET substrates from 1/10-10 times the $K_{m}$ value. The increase of fluorescence over time was continuously recorded for 5-15 min. The kinetic parameters were calculated according to Wilkinson (Wilkinson 1961). One unit of recombinant HtrA2 activity was defined as the amount of enzyme needed to hydrolyse $1 \mu \mathrm{moL}$ of $\mathrm{N} \alpha-\mathrm{RR}-\mathrm{MCA}$ in $1 \mathrm{~min}$. As previously described, the inner-filter effect of the FRET substrates was corrected by an empirical equation (Oliveira et al. 2001).

HPLC analysis of peptides hydrolysed by rHtrA2 Peptide solutions $(50 \mu \mathrm{M})$ in $50 \mathrm{mM}$ Tris- $\mathrm{HCl}, \mathrm{pH} 8.0$, containing $20 \mathrm{mM} \mathrm{NaCl}$ were incubated with rHtrA2 (10 $\mathrm{nM})$ at $37^{\circ} \mathrm{C}$ for $4 \mathrm{~h}$. Samples $(100 \mu \mathrm{L})$ were periodically withdrawn for HPLC analysis. The hydrolysis products were fractionated by reverse-phase HPLC (Class VP, Shimadzu), manually collected and submitted to MS analysis. The HPLC conditions used for the analytical procedure included $0.1 \%$ trifluoroacetic acid in water (solvent $\mathrm{A}$ ) and acetonitrile-solvent A (9:1) as solvent B. The separations were performed at a flow rate of $1 \mathrm{~mL} / \mathrm{min}$ using a JT Baker $\mathrm{C}_{18}$ column $(4.6$ x $300 \mathrm{~mm})$ and a $10-80 \%$ gradient of $\mathrm{B}$ for $30 \mathrm{~min}$. Fractions were monitored for the presence of peptides fragments using an SPD-10AV Shimadzu uv/ vis detector $(214 \mathrm{~nm})$ and a RF-10Ax fluorescence detector $\left(\lambda_{\mathrm{em}}=420 \mathrm{~nm}\right.$ and $\left.\lambda_{\mathrm{ex}}=320 \mathrm{~nm}\right)$.

MS analysis of peptide substrates hydrolysed by rHtrA2 - Peptide fragments were detected by scanning from a $\mathrm{m} / \mathrm{z}$ of $50-2.000$ at $6 \mathrm{~s} / \mathrm{scan}$ with a $31 \mathrm{~V}$ cone. Product-ions from the MS/MS experiments were detected during several scans through the appropriated mass range for each situation using high energy $(25 \mathrm{eV})$ for single-charged precursor ions and low-collision energy $(15 \mathrm{eV})$ for multiple-charged precursor ions. No tandem MS was recorded for peptides smaller than four amino acid residues. Scissile bonds were deduced from the amino acid compositions of the fragments.

Effect of $p H$, temperature and inhibitors on peptidase activity - The $\mathrm{pH}$ studies were performed in $50 \mathrm{mM}$ sodium citrate buffer ( $\mathrm{pH} 3.0$ - 5.3), $50 \mathrm{mM}$ sodium phosphate buffer (pH 5.2 - 7.5) and $50 \mathrm{mM}$ Tris-HCl buffer (pH 7.3 - 10) containing $20 \mathrm{mM} \mathrm{NaCl}$. The stock solutions and the working concentration of the synthetic inhibitors used in the characterisation of HtrA2 proteolytic activity matched those previously described (Dunn et al. 1989). The $\mathrm{pH}$, temperature and peptidase inhibition effects were determined by fluorometric assay using the peptide N $\alpha$-RR-MCA $(10 \mu \mathrm{M})$ as a substrate. The temperature range used was $28-60^{\circ} \mathrm{C}$ and the enzymatic reactions were performed in $50 \mathrm{mM}$ phosphate buffer, $\mathrm{pH} 8.0$.

\section{RESULTS AND DISCUSSION}

Cloning, expression and purification of M. leprae HtrA2 - The gene coding for a putative HtrA2 protease was amplified from $M$. leprae genomic DNA and successfully cloned into the pET32 vector. E. coli BL21 harbouring the recombinant vector was grown in LB medium containing ampicillin and induced by IPTG. The soluble hexa-histidine-tagged fusion protein was purified in one step by immobilised, metal-affinity chromatography from cell lysates using the Ni-NTA resin. A single band corresponding to the recombinant HtrA2 protein with the expected MW of $52.3 \mathrm{kDa}$ was observed in a silver stained SDS-PAGE gel (Fig. 1A). The purified protein was transferred to a nitrocellulose 
membrane and recognised by the anti-6xHis tag antibody (Fig. 1A). A high degree of purity of the recombinant ML0176 was ensured by loading the protein onto a Superdex 75 gel filtration column. The elution profile (Fig. 1B) revealed a single homogeneous peak corresponding to the enzyme, as confirmed by SDS-PAGE followed by trypsin digestion and MS/MS analysis. The following peptides, all matching the predicted amino acid sequence of $M$. leprae ML0176 were sequenced: ${ }^{78} \mathrm{KVVPSVVMLETDLGRQ}^{91},{ }^{132} \mathrm{KTTVTFFDGRT}^{140}$, ${ }^{141}$ RTASFTVVGADPTSDIAVVRV ${ }^{159},{ }^{160}$ RVQSISGLPPITMGSSADLLRV ${ }^{178}$, ${ }^{339}$ RLISSADALVAAVRS $^{351}$ and ${ }^{359}{ }^{K V S L T Y Q D Q S G S S R T}{ }^{371}$.

Primary sequence analysis of M. leprae rHtrA2 Members of the HtrA family share a conserved trypsinlike protease domain and at least one C-terminal PDZ domain, which mediates specific protein-protein interactions and is involved in substrate recognition (Pallen \& Wren 1997, Clausen et al. 2002, Kim \& Kim 2005). Fig. 2 shows the amino-acid sequence alignment among M. leprae HtrA2, HtrA2 from M. tuberculosis H37Rv and DegS from E. coli. M. leprae HtrA2 shares 70\% identity with the M. tuberculosis H37Rv HtrA2 and 26\% identity with DegS. This alignment also indicates conservation in $M$. leprae HtrA2 of common features of the HtrA family members, such as a signal peptide, a trypsin-like domain with the conservation of a puta-

A

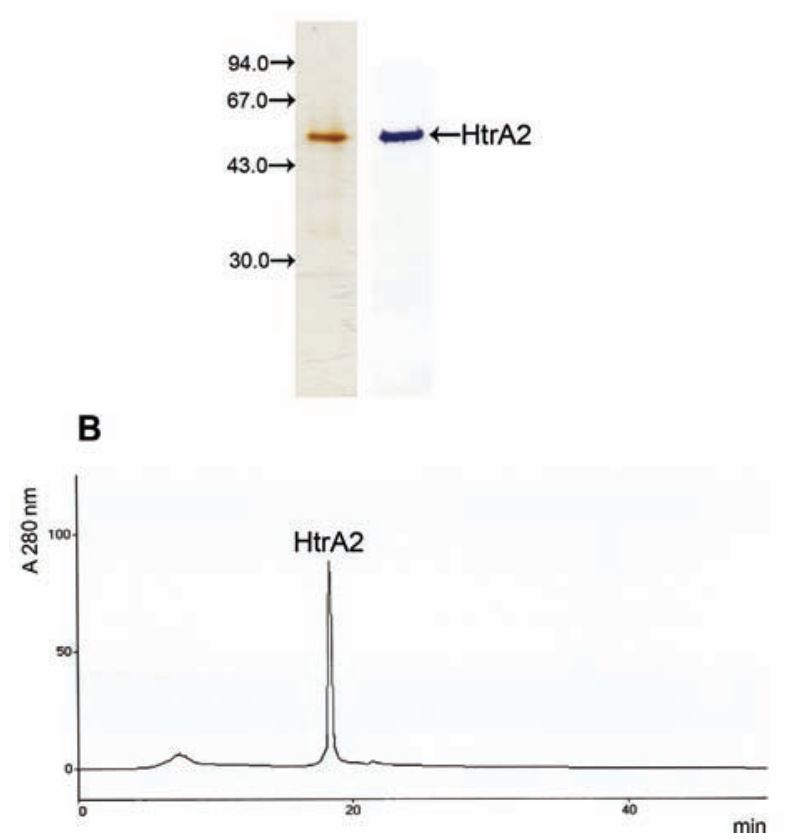

Fig. 1: purification of Mycobacterium leprae high temperature requirement A (HtrA)2. A: SDS-PAGE and Western blot showing the rHtrA2 $(4 \mu \mathrm{g})$ obtained after purification by immobilised metal-affinity chromatography on Ni-NTA resin. The gel was stained with silver and Western blot was developed with anti-His tag antibody. The positions of molecular size markers are shown on the left; B: elution profile of the purified rHtrA protein from a Superdex G75 gel filtration column.

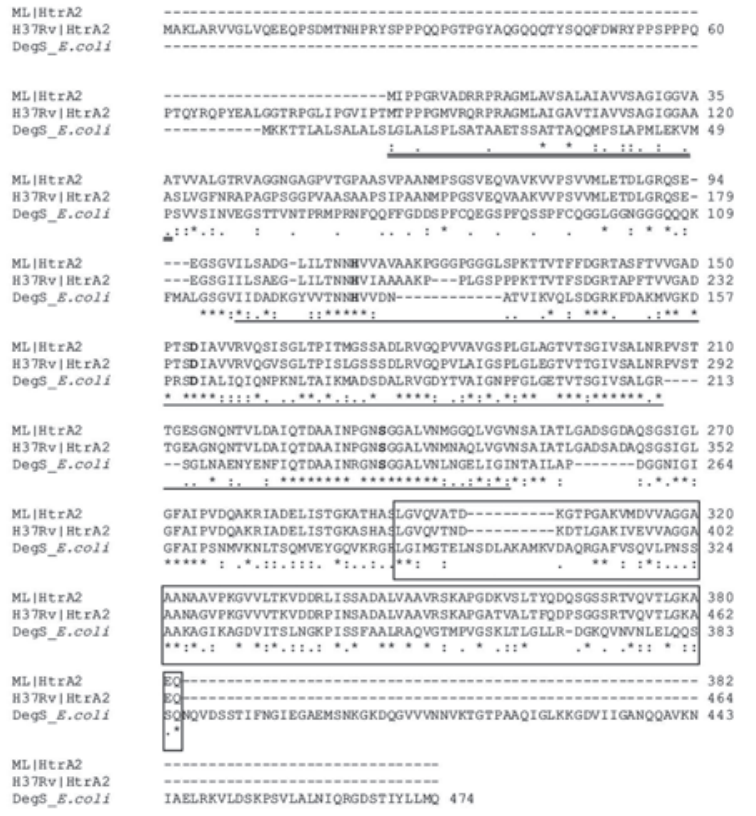

Fig. 2: alignment of the amino acid residues from Mycobacterium leprae and Mycobacterium tuberculosis HtrA2 and Escherichia coli DegS. The signal sequence predicted (CBS 2007) for HtrA2 of $M$. leprae is double underlined (residues 1-36) and the domain for the trypsin family (IPR001254) is underlined (residues 102-249). The conserved residues that likely comprise the catalytic triad are in bold. The PDZ domain (IPR001478) is indicated by an open box (residues 287-382).

tive catalytic triad consisting of the amino acid residues His182, Asp224 and Ser305 and a consensus PDZ domain at the C-terminal region.

Analysis of cleavage specificity and kinetic parameters - HtrA proteins belong to the serine protease clan PA composed of serine proteases that display the following three main types of activity: trypsin-like (the cleavage of the amide bond occurs after Arg or Lys at P1), chymotrypsin-like (cleavage occurs following one of the hydrophobic amino acids at P1) and elastase-like (cleavage following an Ala at P1). A variety of substrates, including synthetic and natural peptides, were then tested for cleavage by the recombinant ML0176 protein.

A collection of 15 synthetic FRET peptides of seven amino acid residues derived from the bradykinin sequence was used as substrates. These peptides allow convenient determination of kinetic parameters because hydrolysis of any peptide bond of the FRET substrates can be easily monitored (Hirata et al. 1995). Table I displays the $K_{m}$, $k_{c a t}$ and $\mathrm{k}_{c a t} / K_{m}$ values that were determined for the hydrolysis of the FRET substrates by M. leprae rHtrA2. All cleaved peptides were hydrolysed at the R-Q bond. The catalytic efficiency $\left(\mathrm{k}_{c a t} / K_{m}\right)$ varied from no hydrolysis of the FRET-2 peptide to $19.90(\mathrm{~s} \cdot \mathrm{mM})^{-1}$ of the FRET-1 peptide. Among the FRET-1 to 6 peptides with variable amino acid residues at the $\mathrm{P} 2$ position, the best substrate was FRET- 1, showing an Arg residue in this position. In contrast, the presence of Asp at position P2 (FRET- 
2) resulted in a total absence of interaction between the enzyme and the substrate. The FRET-7 to 9 peptides revealed that rHtrA from $M$. leprae preferred amino acid residues with an aliphatic chain, like Ile or Leu, instead of Phe at P3. Among the FRET-10 to 15 peptides with amino acid residue changes at $\mathrm{P} 4$, the best substrate was FRET-12 with an Arg residue at this position.

Five naturally-occurring peptides of various sizes and amino acid sequences were also tested for cleavage by the enzyme. Hydrolysis was monitored by HPLC and the results are summarised in Table II. The most susceptible substrate was neurotensin, which presented one minor (R8 $\downarrow$ R9) and two major cleavage sites (Y3 $\downarrow$ E4 and Y11 $\downarrow 12)$. When dynorphin was the substrate, rHtrA2 showed a preference for hydrolysis involving basic amino acid residues in a $\mathrm{P} 1$ position (R6 $\downarrow \mathrm{R} 7$ and $\mathrm{R} 7 \downarrow 18$ ). $M$. leprae rHtrA2 failed to hydrolyse oxytocin, angiotensin I and bradykinin, although the sequences of the latter two peptides contain basic residues.

The proteolytic activity profile displayed by $M$. leprae rHtrA2 over the FRET and naturally occurring peptides suggest that this enzyme recognises the substrate via P1$\mathrm{S} 1$ and through an extended interaction site. In contrast, other HtrA family member activity has been predicted to depend solely on what is present in the P1 position (Kim \& Kim 2005, Hauske et al. 2009). Moreover, M. leprae rHtrA2 was able to cleave after basic and hydrophobic residues. In this way, M. leprae rHtrA2 seems to display a broader cleavage specificity than has been described in the context of E. coli DegP and DegS, which have shown restricted cleavage preference after hydrophobic residues (Clausen et al. 2002, Jones et al. 2002).

Physicochemical properties - Further characterisation of $M$. leprae rHtrA2 was performed using N $\alpha$-RRMCA, which has only one cleavage site at the R-MCA

\section{TABLE II}

Hydrolysis of bioactive peptides by rHtrA2

\begin{tabular}{|c|c|c|}
\hline Substrate & $\begin{array}{l}\text { Rates of hydrolysis } \\
\text { (nmol/ } / \mathrm{g} / \mathrm{min})\end{array}$ & Peptide sequence $^{a}$ \\
\hline Dynorphin $\mathrm{A}_{1-13}$ & 112 & YGGFLR $\downarrow R \downarrow I R P K L K$ \\
\hline Neurotensin & 85 & ELY $\downarrow E N K P R \downarrow R P Y \downarrow I L$ \\
\hline Angiotensin I & $\mathrm{nh}$ & DRVYIHPFHL \\
\hline Bradykinin & $\mathrm{nh}$ & RPPGFSPFR \\
\hline Oxytocin & $\mathrm{nh}$ & CYIQNCPLG \\
\hline
\end{tabular}

$a$ : cleavage sites determined by mass spectrometry (MS) analysis are indicated by $\downarrow$. Assays were carried out in $300 \mu \mathrm{L}$ of $50 \mathrm{mM}$ Tris-HCl buffer, $\mathrm{pH} 8.0$, at $42^{\circ} \mathrm{C}$, using $50 \mu \mathrm{M}$ of each peptide and $5 \mathrm{nM}$ of rHtrA2. Control samples were identical, except that the enzyme was omitted. After $30 \mathrm{~min}$, the reactions were stopped with TFA $(0.1 \%)$ and the hydrolysis rates were determined by comparing the peak areas of control samples versus digested samples. The peaks were manually collected and submitted to MS analysis for cleavage bond determinations. nh: no hydrolysis detected. position, as a substrate. Fig. 3A shows that N $\alpha-R R-M C A$ was efficiently cleaved by M. leprae rHtrA2.

To confirm the class of the protease, tests were performed to determine whether the activity of $M$. leprae rHtrA2 was affected by PMSF and aprotinin, two classical inhibitors of serine peptidases. The proteolytic activity of $M$. leprae rHtrA2 was markedly reduced by both inhibitors and at $4.2 \mathrm{mU}$ aprotinin was able to completely inactivate the enzyme (Fig. 3A).

The effect of $\mathrm{pH}$ on the catalytic activity of the enzyme was studied at $37^{\circ} \mathrm{C}$ between $\mathrm{pH} 4.0-10.0$. The $\mathrm{pH}$ curve displayed maximal activity at $\mathrm{pH}$ ranging from 7.5-9.0, as

\begin{tabular}{lcc} 
A & & \\
\hline Inhibitors & Velocity $\left(\mathrm{nmol} / \mathrm{g}^{-1} \cdot \mathrm{min}^{-1}\right)$ & Residual activity (\%) \\
\hline Control & 0.0861 & 100 \\
PMSF $(1 \mathrm{mM})$ & 0.0115 & 13 \\
Aprotinin $(4.2 \mathrm{U})$ & $\mathrm{nh}$ & 0 \\
\hline
\end{tabular}
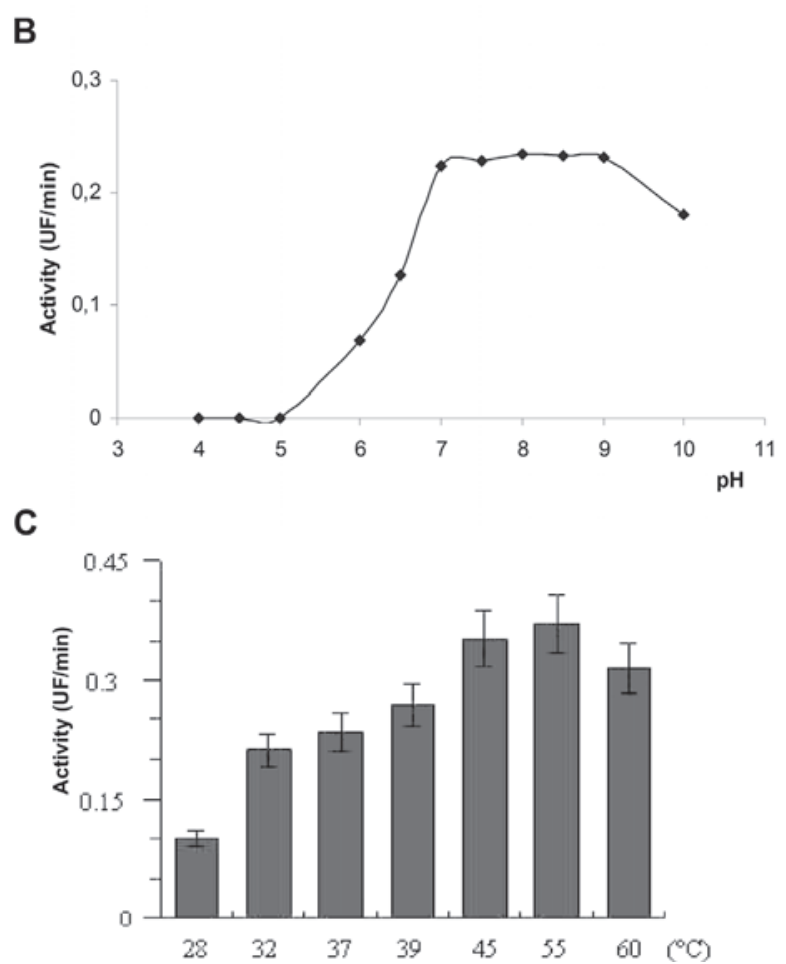

Fig. 3: physicochemical properties of Mycobacterium leprae rHtrA2. A: effect of serine protease inhibitors on rHtrA2 activity. Assays were carried out in $500 \mu \mathrm{L}$ of $50 \mathrm{mM}$ phosphate buffer, $\mathrm{pH} 8.0$, at $37^{\circ} \mathrm{C}$ and enzymatic activities were measured by fluorometric assays using $5 \mu \mathrm{M}$ $\mathrm{N} \alpha$-RR-MCA as substrate. One hundred percent represents HtrA2 hydrolysis of $\mathrm{N} \alpha-\mathrm{RR}-\mathrm{MCA} / \mathrm{min}$ in the absence of an inhibitor. Purified rHtrA2 ( $2 \mathrm{mU}$ ) was incubated in the presence of $1 \mathrm{mM}$ PMSF or $4.2 \mathrm{mU}$ aprotinin under the conditions described above. B: effect of $\mathrm{pH}$ upon rHtrA2 enzymatic activity. The $\mathrm{pH}$ studies were performed at $37^{\circ} \mathrm{C}$ in $50 \mathrm{mM}$ sodium citrate buffer (pH 3.0 - 5.3), 50 mM sodium phosphate buffer $(\mathrm{pH}$ 5.2-7.5) and $50 \mathrm{mM}$ Tris-HCl buffer (pH 7.3-10). The enzymatic activity was determined as in A: C: effect of temperature on rHtrA2 activity. The experiments were carried out at the stated temperatures using the same buffer and substrate as in A. Enzymatic assays were carried out under the same conditions as in A, except for temperature variation. Data represent the mean of three independent experiments. nh: no hydrolysis detected. 
shown in Fig. 3B. The activity of the enzyme was also investigated at various temperatures from $28-60^{\circ} \mathrm{C}$. Fig. 3C shows that $M$. leprae rHtrA2 was active at a broad range of temperatures, reaching maximum activity at $45-55^{\circ} \mathrm{C}$. This preference for high temperatures is a typical feature of proteases belonging to the HtrA family (Clausen et al. 2002, Kim \& Kim 2005). Indeed, classical HtrA proteases possess a temperature-dependent functional switch that makes it possible to transform a formerly chaperoned activity to one of protease. At low temperatures, these enzymes exhibit activity of molecular chaperones, while their proteolytic activities rapidly increase between 32$42^{\circ} \mathrm{C}$ (Skorko-Glonek et al. 2007, 2008). The details of the chaperone activity of $M$. leprae HtrA2 and the question of whether this enzyme displays a similar temperaturedependent functional switch from chaperone to protease activity requires further investigation.

Taken together, our results confirm that ML0176 codes for a serine protease, displaying the physicochemical characteristics typical of an HtrA protein. The possible role of HtrA2 in leprosy remains to be studied and is under investigation in our laboratory. Excitingly, it has recently been reported that HtrA2 deletion in $M$. tuberculosis results in virulence attenuation, with decreased extent of pathology and longer survival times, in a mouse model of tuberculosis (MohamedMohaideen et al. 2008). Moreover, a biochemical analysis of this protein showed serine protease activity towards $\beta$-casein and chaperone behaviour. This study also determined the three-dimensional structure of $M$. tuberculosis HtrA2, raising the possibility of designing effective specific inhibitors to this enzyme, which may contribute to novel therapeutic treatment of leprosy and tuberculosis.

\section{ACKNOWLEDGMENTS}

To Natalia Pierangeli dos Santos, for her technical assistance.

\section{REFERENCES}

Biet F, Marques A de MM, Grayon M, Xavier da Silveira EK, Brennan PJ, Drobecq H, Raze D, Vidal Pessolani MC, Locht C, Menozzi FD 2007. Mycobacterium smegmatis produces an HBHA homologue which is not involved in epithelial adherence. Microbes Infect 9: 175-182.

Biswas S, Biswas I 2005. Role of HtrA in surface protein expression and biofilm formation by Streptococcus mutans. Infect Immun 73: 6923-6934.

Bradford MM 1976. A rapid and sensitive method for the quantification of microgram quantities of protein utilizing the principle of protein-dye binding. Anal Biochem 72: 248-254.

CBS - Center for Biological Sequence Analysis 2007. CBS prediction server. [updated 2007 Aug 24; cited 2009 Mar 02]. Available from: http://www.cbs.dtu.dk/services/SignalP/.

Clausen T, Southan C, Ehrmann M 2002. The HtrA family of proteases: implications for protein composition and cell fate. $\mathrm{Mol}$ Cell 10: 443-455.

Dunn BM, Beynon HRJ, Bond JS 1989. Proteolytic enzymes: a practical approach, Oxford University Press, Oxford, 340 pp.

Flannagan RS, Aubert D, Kooi C, Sokol PA, Valvanoi MA 2007. Burkholderia cenocepacia requires a periplasmic HtrA protease for growth under thermal and osmotic stress and for survival in vivo. Infect Immun 75: 1679-1689.
García García JM, Gutierrez JJP, Antunã AAS 2005. Respiratory infections caused by environmental mycobacteria. Arch Bronconeumol 41: 206-219.

Hauske P, Meltzer M, Ottmann C, Krojer T, Clausen T, Ehrmann M, Kaiser M 2009. Selective profiling of DegP substrates and inhibitors. Bioorg Med Chem 17: 2920-2924.

He H, Hovey R, Kane J, Singh V, Zahrt TC 2006. MprAB is a stressresponsive two-component system that directly regulates expression of sigma factors SigB and SigE in Mycobacterium tuberculosis. J Bacteriol 188: 2134-2143.

He H, Zahrt TC 2005. Identification and characterization of a regulatory sequence recognized by Mycobacterium tuberculosis persistence regulator MprA. J Bacteriol 187: 202-212.

Hirata IY, Cezari MH, Nakaie CR, Boschcov P, Ito AS, Juliano MA, Juliano L 1995. Internally quenched fluorogenic protease substrates: Solid-phase synthesis and fluorescence spectroscopy of peptides containing ortho-aminobenzoyl/dinitrophenyl groups as donor-acceptor pairs. Lett Pept Sci 1: 299-308.

Huston WM, Theodoropoulos C, Mathews SA, Timms P 2008. Chlamydia trachomatis responds to heat shock, penicillin induced persistence and IFN-gamma persistence by altering levels of the extracytoplasmic stress response protease HtrA. BMC Microbiol 8: 190-206.

Jones CH, Bolken TC, Jones KF, Zeller GO, Hruby DE 2001. Conserved DegP protease in Gram-positive bacteria is essential for thermal and oxidative tolerance and full virulence in Streptococcus pyogenes. Infect Immun 69: 5538-5545.

Jones CH, Dexter P, Evans AK, Liu C, Hultgren SJ, Hruby DE 2002. Escherichia coli DegP protease cleaves between paired hydrophobic residues in a natural substrate: the PapA pilin. J Bacteriol 184: 5762-5771.

Kim DY, Kim KK 2005. Structure and function of HtrA family proteins, the key players in protein quality control. J Biochem Mol Biol 38: 266-274.

Kolmar H, Waller PRH, Sauer RT 1996. The DegP and DegQ periplasmic endoproteases of Escherichia coli: specificity for cleavage sites and substrate conformation. J bacteriol 178: 5925-5929.

Krojer T, Sawa J, Schafer E, Saibil HR, Ehrmann M, Clausen T 2008. Structural basis for the regulated protease and chaperone function of DegP. Nature 453: 885-892.

Lewis C, Skovierova H, Rowley G, Rezuchova B, Homerova D, Stevenson A, Spencer J, Farn J, Kormanec J, Roberts M 2009. Salmonella enterica Serovar Typhimurium HtrA: regulation of expression and role of the chaperone and protease activities during infection. Microbiology 155: 873-881.

Lipinska B, Fayet O, Baird L, Georgopoulos C 1989. Identification, characterization and mapping of the Escherichia coli htrA gene, whose product is essential for bacterial growth only at elevated temperatures. J Bacteriol 171: 1574-1584.

Lipinska B, Zylicz M, Georgopoulos C 1990. The HtrA (DegP) protein, essential for Escherichia coli survival at high temperatures, is an endopeptidase. J Bacteriol 172: 1791-1797.

Marques MA, Neves-Ferreira AGC, Xavier da Silveira EK, Valente $\mathrm{RH}$, Chapeaurouge A, Perales J, Bernardes RS, Dobos KM, Spencer JS, Brennan PJ, Pessolani MCV 2008. Deciphering the proteomic profile of Mycobacterium leprae cell envelope. Proteomics 8: 2477-2491.

Mo E, Peters SE, Willers C, Maskell DJ, Charles IG 2006. Single, double and triple mutants of Salmonella enterica serovar Typhimurium $\operatorname{deg} \mathrm{P}(\mathrm{htr} \mathrm{A}), \operatorname{deg} \mathrm{Q}(\mathrm{hhoA})$ and $\operatorname{degS}(\mathrm{hhoB})$ have diverse phenotypes on exposure to elevated temperature and their growth in vivo is attenuated to different extents. Microb Pathog 41: 174-182. 
MohamedMohaideen NN, Palaninathan SK, Morin PM, Williams BJ, Braunstein M, Tichy SE, Locker J, Russell DH, Jacobs WR, Sacchettini JC 2008. Structure and function of the virulenceassociated high-temperature requirement A of Mycobacterium tuberculosis. Biochemistry 47: 6092-6102.

Oliveira V, Campos M, Melo RL, Ferro ES, Camargo ACM, Juliano MA, Juliano L 2001. Substrate specificity characterization of recombinant metallo oligo-peptidases thimet oligopeptidase and neurolysin. Biochemistry 40: 4417-4425.

Page MJ, Di Cera E 2008. Serine peptidases: classification, structure e function. Cell Mol Life Sci 65: 1220-1236.

Pallen MJ, Wren BW 1997. The HtrA family of serine proteases. Mol Microbiol 26: 209-221.

Ribeiro-Guimarães ML, Pessolani MCV 2007. Comparative genomics of mycobacterial proteases. Microb Pathog 43: 173-178.

Ribeiro-Guimarães ML, Tempone AJ, Amaral JJ, Nery JA, Antunes SLG, Pessolani MCV 2007. Expression analysis of proteases of Mycobacterium leprae in human skin lesions. Microb Pathog 43: 249-254.

Skorko-Glonek J, Laskowska E, Sobiecka-Szkatula A, Lipinska B 2007. Characterization of the chaperone-like activity of HtrA (DegP) protein from Escherichia coli under the conditions of heat shock. Arch Biochem Biophys 464: 80-89.
Skorko-Glonek J, Sobiecka-Szkatula A, Narkiewicz J, Lipinska B 2008. The proteolytic activity of the HtrA (DegP) protein from Escherichia coli at low temperatures. Microbiology 154: 3649-3658.

Stack HM, Sleator RD, Bowers M, Hill C, Gahan CGM 2005. Role for HtrA in stress induction and virulence potential in Listeria monocytogenes. Applied Environmental Microbiology 71: 4241-4247.

Yuan L, Rodrigues PH, Bélanger M, Dunn WA, Progulske-Fox A 2008. Porphyromonas gingivalis htrA is involved in cellular invasion and in vivo survival. Microbiology 154: 1161-1169.

WHO - World Health Organization 2009a. Programmes and special initiatives. Stop TB. [updated 2009 Aug 12; cited 2009 Apr 02]. Available from: http://www.wpro.who.int/sites/stb/overview.htm.

WHO - World Health Organization 2009b. Programmes and special initiatives. Leprosy elimination. [updated 2009 Aug 19; cited 2009 Apr 02]. Available from: http://www.wpro.who.int/sites/leprosy.

Wilkinson GR 1961. Statistical estimations in enzyme kinetics. Biochem J 80: 324-332.

Zahrt TC, Deretic V 2001. Mycobacterium tuberculosis signal transduction system required for persistent infections. Proc Natl Acad Sci USA 98: 12706-12711.

Zahrt TC, Wozniak C, Jones D, Trevett A 2003. Functional analysis of the Mycobacterium tuberculosis MprAB two-component signal transduction system. Infect Immun 71: 6962-6970. 